\title{
PENGGUNAAN LIMBAH SERBUK BESI SEBAGAI CAMPURAN AGREGAT HALUS PADA ASPHALT CONCRETE-WEARING COURSE (AC-WC)
}

\author{
Umma Chintya Devi ${ }^{1}$ dan Nur Azizah Affandy ${ }^{2}$ \\ ${ }^{1}$ Program Studi Teknik Sipil, Universitas Islam Lamongan, J1. Veteran No.53 A Lamongan \\ ummachintyadevi@gmail.com \\ ${ }^{2}$ Program Studi Teknik Sipil, Universitas Islam Lamongan, Jl. Veteran No.53 A Lamongan \\ nurazizah@unisla.ac.id
}

\begin{abstract}
As time goes by, roads are easily damaged due to the large number of transportation that passes. For this reason, the development of new findings is continuously being made to improve the strength of the road layers. In this study, iron powder waste was used because from a physical perspective, iron powder is very similar to fine aggregate. In this study, iron powder waste was used as an additive for fine aggregate with a content of $0 \%, 4 \%, 4.5 \%, 5 \%$ by weight of fine aggregate. The purpose of this study was to determine the effect of iron powder waste on Marshall Properties parameters. This study uses the Marshall Properties test method consisting of stability (kg), VIM (\%), VMA (\%), VFA (\%), Flow and Marshall Quotien. For the best results from the comparison of asphalt with $0 \%$ content and asphalt with added ingredients, namely stability $0 \%$ yield $997 \mathrm{~kg}$ and $4 \%$ yield $788 \mathrm{~kg}$, Flow $0 \%$ yield $3.17 \mathrm{~mm}$ and $4 \%$ yield $3.33 \mathrm{~mm}$, VMA $0 \%$ yield $17.29 \%$ and $4 \%$ yield $15.84 \%$, VIM $0 \%$ yield $4.14 \%$ and $4 \%$ yield $2.46 \%$, VFA $0 \%$ yield $74.97 \%$ and $5 \%$ yield $88.76 \%$ and $M Q 0 \%$ yields of $309.31 \mathrm{~kg} / \mathrm{mm}$ and $5 \%$ yields of 246.80 $\mathrm{kg} / \mathrm{mm}$. From here it can be seen that the level of $4 \%$ more shows the best results and meets the standards.
\end{abstract}

Keywords: Iron Powder; Marshall; Filler; Asphalt AC-WC

\begin{abstract}
ABSTRAK
Seiring berkembangnya jaman, jalan mudah sekali mengalami kerusakan karena banyaknya transportasi yang melintas. Untuk itu, pengembangan temuan baru terus dilakukan untuk memperbaiki kekuatan lapisan jalan. Dalam penelitian ini digunakan limbah serbuk besi karena dari segi fisik, serbuk besi sangat mirip dengan agregat halus. Dalam penelitian ini, limbah serbuk besi digunakan untuk bahan tambah agregat halus dengan kadar $0 \%, 4 \%, 4.5 \%$, $5 \%$ dari berat agregat halus. Tujuan dari penelitian ini adalah untuk mengetahui pengaruh dari limbah serbuk besi terhadap parameter Marshall Properties. Penelitian ini menggunakan metode pengujian Marshall Properties yang terdiri dari Stabilitas (kg), VIM (\%), VMA (\%), VFA (\%), Flow dan Marshall Quotien. Untuk hasil terbaik dari perbandingan aspal dengan kadar 0\% dan aspal dengan bahan tambah yaitu stabilitas $0 \%$ hasil $997 \mathrm{~kg}$ dan $4 \%$ hasil $788 \mathrm{~kg}$, Flow $0 \%$ hasil $3,17 \mathrm{~mm}$ dan $4 \%$ hasil $3,33 \mathrm{~mm}$, VMA $0 \%$ hasil $17,29 \%$ dan $4 \%$ hasil $15,84 \%$, VIM $0 \%$ hasil 4,14\% dan 4\% hasil 2,46\%, VFA 0\% hasil 74,97\% dan 5\% hasil 88,76\% dan MQ 0\% hasil 309,31 kg/mm dan $5 \%$ hasil 246,80 kg/mm. Dari sini dapat dilihat kadar 4\% lebih banyak menunjukan hasil terbaik dan hampir memenuhi standart.
\end{abstract}

Kata kunci: Serbuk Besi; Marshall; Filler; Aspal AC-WC

\section{PENDAHULUAN}

\section{Latar belakang}

Jalan raya merupakan lapis perkerasan yang lapisannya dimulai dari tanah dasar, lapis pondasi dan lapis Jalan raya merupakan lapis perkerasan yang lapisannya dimulai dari tanah dasar, lapis pondasi dan lapis permukaan aspal. (Budianto \& Lubis, 2020) Kekuatan dan keawetan suatu perkerasan jalan sangat ditentukan oleh daya dukung tanah, karena jenis aspal dan agregat-agregat yang digunakan sebagai bahan utama dalam pembuatan perkerasan lentur jalan. Dengan seiring berkembangnya jaman, banyak transportasi yang melintasi jalan dan membuat lapisan jalan semakin cepat rusak. Berbagai usaha dalam mengembangkan temuan baru untuk memperbaiki kekuatan jalan agar tidak cepat rusak. (Arifiardi Winoto; Purnomo, Adhi, 2016) Dalam aspal beton dikembangkan menjadi tiga bagian yaitu lapis tipis pasir (latasir), lapis tipis aspal beton (lataston) dan lapis tipis aspal beton (laston). Dalam penelitian ini menggunakan limbah serbuk besi yang berasal dari sisa bubutan besi yang tidak terpakai dan terbuang begitu 
saja. Penggunaan limbah serbuk besi ini bertujuan untuk mengurangi pencemaran lingkungan, karena serbuk besi merupakan logam yang akan merusak alam jika pembuangan limbahnya tidak diolah terlebih dahulu. Selain itu, penelitain ini bertujuan untuk mengurangi permasalahan yang sering terjadi pada jalan raya, yaitu kerusakan akibat beban, genangan air maupun cuaca panas.

\section{Penelitian terdahulu}

Pada penelitian yang menggunakan pasir besi dan semen sebagai filler dalam aspal AC-WC, mempunyai kadar campuran kombinasi filler $100 \%$ pasir besi, 50\% pasis besi dengan 50\% semen dan 100\% semen yang dalam kondisi kering serta terendam air. Dari pengujian tersebut menunjukkan hasil stabilitas tertinggi pada campuran filler $50 \%$ pasir besi dengan $50 \%$ semen (Susanto, 2020).

Dalam pengganti sejumlah filler dengan limbah serbuk besi terhadap HRS (Hot Rolled Shett) untuk mengetahui seberapa besar pengaruh limbah serbuk besi terhadap stabilitas dan flow dengan kadar variasi $0 \%, 5 \%, 10 \%$ dan $20 \%$. Untuk variasi $5 \%$ dan $10 \%$ sudah memenuhi persyaratan sebagai filler, tetapi untuk hasil paling tinggi stabilitas dan flow terdapat pada kadar 10\% (Santosa, 2019).

Tujuan dari penelitian pengaruh serbuk besi terhadap marshall dan sifat volumetrik aspal beton ini, untuk mengetahui pengaruh besi sebagai sifat volumetrik dan sifat marshall. Penambahan dengan kadar variasi 2\%, 4\%, $6 \%$ dan $8 \%$ dari berat agregat halus. Dapat disimpulkan bahwa hasil penambahan serbuk besi dapat meningkatkan sifat marshall dan volumetrik aspal. Untuk stabilitas meningkat $15 \%$ pada kadar variasi $2 \%$, nilai VMA menurun seiring pertambahan persentase kadar dan VFA tidak terpengaruh secara signifikan. Rasio ideal pengarsipan serbuk besi yang memenuhi persyaratan optimal adalah 5\% (Al-tuwayyij \& Issa, 2020).

Dalam pemanfaatan limbah serbuk besi sebagai agregat halus pada aspal panas dengan tujuan mencari pengaruh dan juga perbandingan nilai karakteristik marshall. Pemanfaatan limbah serbuk besi dengan kadar 0\%, 25\%, 50\%, 75\% dan $100 \%$. Untuk hasil penelitian yang memenuhi standart spesifikasi aspal optimum dan uji marshall hanya pada variasi 0\% dan 25\%. Kadar 25\% merupakan kadar tertinggi yang memenuhi parameter marshall (Bahri, 2017).

Dan dalam penelitian ini mencoba menggunakan limbah serbuk besi sebagai bahan tambah agregat halus. Seperti pada refrensi penelitian terdahulu diatas, bahwa hasil yang memenuhi standart adalah hasil yang terendah yaitu $25 \%$ maka dari itu, pada penelitian ini menggunakan kadar variasi $0 \%, 4 \%, 4.5 \%$ dan 5\% dari berat agregat halus yang kadarnya dibawah 25\%. Dan hasilnya pada kadar 4\% yang hampir memenuhi seluruh parameter marshall. Serbuk besi dari penelitian ini mempunyai ukuran $0,3 \mathrm{~mm}$ atau lolos ayakan No.50 dan kebanyakkan dari penelitian terdahulu menggunakan serbuk besi dengan ukuran 0,075 mm atau lolos No.200.

\section{Karakteristik serbuk besi}

Serbuk besi berasal dari gergaji atau bubutan besi yang teksturnya mirip dengan pasir, mempunyai ukuran $0,3 \mathrm{~mm}$ dan lolos ayakan No.50. Serbuk besi sendiri mempunyai bentuk tergantung dari cara pembuatannya, seperti berbentuk bulat, pipih dan tidak teratur, mempunyai berat jenis semu dalam kilogram per meter kubik, yang mana harga harus tetap agar jumlah pada setiap waktu tidak berubah, mempunyai kehalusan dengan ayakan standart mesh untuk mengetahui ukuran dan distribusi penentuan ukuran partikel dan memiliki sifat sinter yaitu pengikatan suatu partikel dalam proses pemanasan.

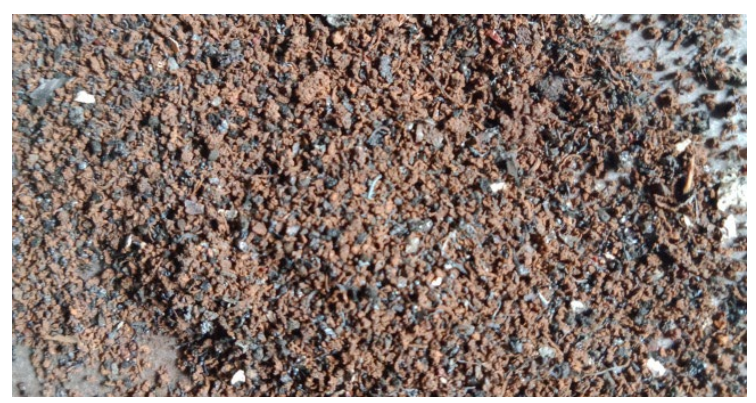

Gambar 1. Limbah serbuk besi sebelum diayak 


\section{METODE PENELITIAN}

Penelitian ini dilakukan pada Laboratorium Teknik Sipil Universitas Islam Lamongan yang dimulai dari analisan bahan, pembuatan benda uji hingga pengujian benda uji. Dalam penelitian ini menggunakan campuran Asphalt Concrete Wearing Course (AC-WC) yang terdisi dari agregat kasar, agregat halus, filler, aspal dan bahan tambah limbah serbuk besi dengan kadar variasi $0 \%, 4 \%, 4.5 \%, 5 \%$ dari berat agregat halus. Sebelum digunakan serbuk besi diseleksi hingga memiliki gradasi yang sesuai standart dengan gradasi agregat halus. Dan untuk aspal yang digunakan yaitu memiliki penetrasi 60/70.

\section{Tahapan penelitian}

1. Persiapan

Dimulai dari tahapan perumusan masalah, persiapan pelaksanaan, bahan, peralatan dan analisa data.

2. Pemeriksaan bahan susun

Pemeriksaan agregat kasar, agregat halus, filler, aspal dan serbuk besi yang dimulai dari :

a. Analisa agregat kasar yaitu : berat jenis curah, berat jenis SSD dan penyerapan. Standart yang digunakan ialah SNI 1969-2008.

b. Analisa agregat halus yaitu : berat jenis curah, berat jenis SSD dan penyerapan. Standart yang digunakan ialah SNI 1970-2008.

c. Untuk pengujian filler mengacu pada (Direktorat Jenderal Bina Marga, 2010) yang lolos ayakan No.200 dengan menggunkan filler semen.

d. Serbuk besi yang mana telah diayak sesuai kebutuhan yaitu lolos ayakan No.4 sesuai standart agregat halus.

e. Pemeriksaan aspal

1) Penetrasi aspal yang dilakukan sesuai standart (SNI 06-2456, 1991)

2) Pengujian titik nyala menurut (SNI 06-2433, 1991)

3) Pengujian titik bakar menurut (SNI 06-2433, 1991)

4) Dan titik lembek menurut (SNI 06-2434, 1991)

3. Pembuatan benda uji

Setelah ditentukan bahan susun dan diuji sesuai dengan persyaratan, kemudian dilakukan pencampuran (Job Mix Formula). Untuk bahan campuran limbah serbuk besi dalam keadaan kering (Dry Mix) dan juga lolos ayakan sesuai standart agregat halus yaitu lolos ayakan 4,7 mm (No.4) denga kadar variasi yaitu 0\%, 4\%, 4.5\%, 5\% dari berat agregat halus. Berat kadar variasi serbuk besi 4\% yaitu 48 gram, 4.5\% yaitu 54 gram dan 5\% yaitu 60 gram. Pembuatan benda uji masing-masing kadar adalah 3 buah, maka dari itu total benda uji adalah 12 buah benda uji, dengan proses pemadatan 75 x 2. Dilakukan pengujian Marshall Test yang sebelumnya benda uji direndam dalam waterbath selama 30 menit dengan suhu $60^{\circ} \mathrm{C}$ dan pengujian alat untuk mengetahui Stabilitas dan Flow. Melakukan analisa dan pembahasan untuk mengetahui hasil dari penelitian tersebut apakah sudah memenuhi persyaratan atau tidak. Untuk hasil akhir dilakukan penyimpulan dari data yang telah diperoleh.

\section{HASIL DAN PEMBAHASAN}

\section{Hasil pemeriksaan agregat kasar}

Hasil dari pemeriksaan karakteristik agregat kasar pecah lolos ayakan no.4 maks. 2\% yang diperoleh dari Laboratorium Universitas Islam Lamongan berdasarkan persyaratan spesifikasi (SNI 1969, 2008). Hasil pengujian dapat dilihat pada Tabel 1 . 
Tabel 1. Standar acuan agregat kasar

\begin{tabular}{lllcccc}
\hline No. & \multicolumn{1}{c}{ Nama Data } & Standart Acuan & Syarat & Satuan & $\begin{array}{c}\text { Hasil } \\
\text { Perhitungan }\end{array}$ & Keterangan \\
\hline 1. & Berat Jenis Curah (Bulk) & SK SNI 1969-2008 & $\geq 2,5$ & $\%$ & 2,55 & Memenuhi \\
2. & Berat Jenis SSD & SK SNI 1969-2008 & $\geq 2,5$ & $\%$ & 2,66 & Memenuhi \\
3. & Berat Jenis Semu & SK SNI 1969-2008 & $\geq 2,5$ & Gr/cc & 3,10 & Memenuhi \\
4. & Penyerapan & SK SNI 1969-2008 & $\leq 2,5$ & Gr/cc & 0,15 & Memenuhi \\
\hline
\end{tabular}

Dari tabel diatas diketahui, bahwa untuk pengujian agregat kasar yang meliputi berat jenis curah, berat jenis SSD, berat jenis semu dan penyerapan semunya sudah memenuhi standart SNI 1969-2008.

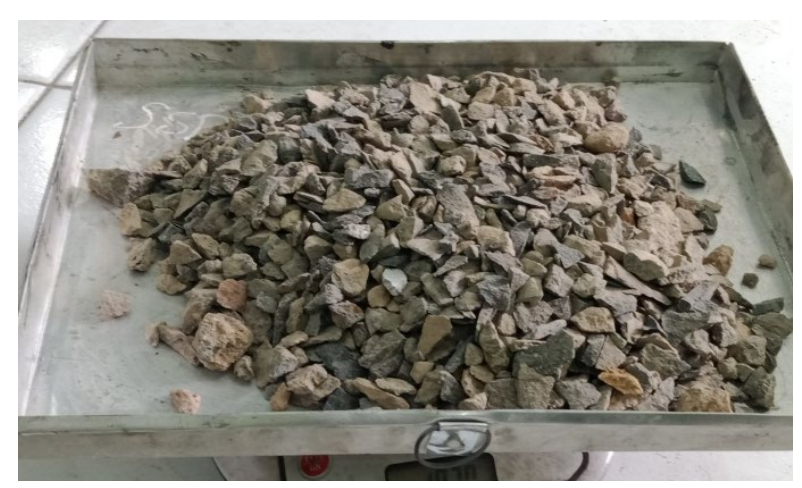

Gambar 2. Agregat kasar

\section{Hasil pemeriksaan agregat halus}

Hasil pemeriksaan agregat halus yang lolos ayakan 4,7 $\mathrm{mm}$ dan tidak boleh mengandung lumpur maksimal 5\% berdasarkan persyaratan spesifikasi (SNI 03-1970, 2008). Hasil pengujian dapat dilihat pada Tabel 2.

Tabel 2. Standar acuan agregat halus

\begin{tabular}{llrcccc}
\hline No. & \multicolumn{1}{c}{ Nama Data } & Standart Acuan & Syarat & Satuan & $\begin{array}{c}\text { Hasil } \\
\text { Perhitungan }\end{array}$ & Keterangan \\
\hline 1. & Berat Jenis Curah (Bulk) & SK SNI 1970-2008 & $\geq 2,5$ & $\%$ & 2,88 & Memenuhi \\
2. & Berat Jenis SSD & SK SNI 1970-2008 & $\geq 2,5$ & $\%$ & 3,52 & Memenuhi \\
3. & Berat Jenis Semu & SK SNI 1970-2008 & $\geq 2,5$ & Gr/cc & 7,9 & Memenuhi \\
4. & Penyerapan & SK SNI 1970-2008 & $\leq 3,0$ & Gr/cc & 0,21 & Memenuhi \\
\hline
\end{tabular}

Tabel 2. Menunjukkan hasil dari pengujian agregat halus sudah memenuhi standart SNI 1970-2008 yang terdiri dari berat jenis curah, berat jenis SSD, berat jenis semu dan penyerapan.

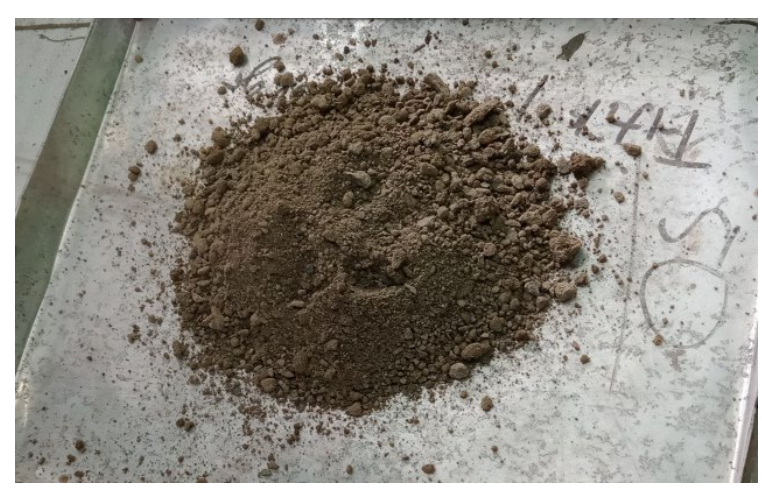

Gambar 3. Agregat halus 


\section{Pengujian filler}

Spesifikasi dari pengujian filler mengacu pada (Direktorat Jenderal Bina Marga, 2010) yaitu lolos saringan no.200 sebanyak 75\% dari hasil pengujian. Tabel 3 hasil kadar filler.

Tabel 3. Kadar filler

\begin{tabular}{cccc}
\hline Filler & Lolos Ayakan & Kadar $(\%)$ & Berat (gram) \\
\hline Semen & No.200 & $2 \%$ & 22,6 \\
\hline
\end{tabular}

Pada tabel 3. Digunakan filler semen dalam campuran aspal. Penggunaan filler sebagai bahan pengisi rongga dan juga dapat mengikat antara agregat dan aspal.

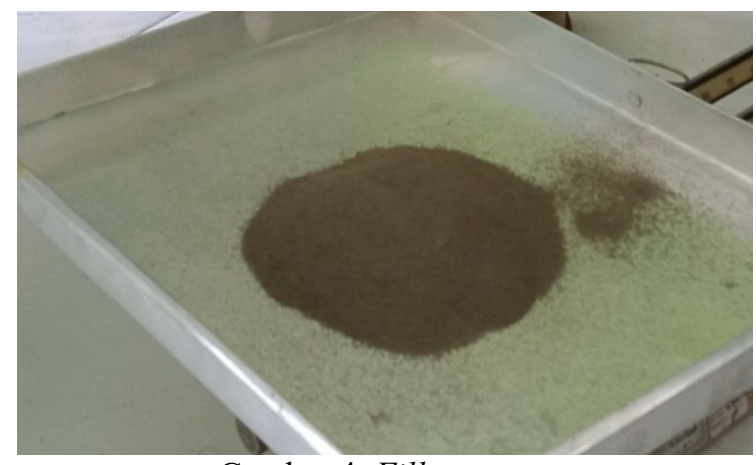

\section{Serbuk besi}

Gambar 4. Filler semen

Serbuk besi berasal dari hasil sisa bubutan atau potongan besi. Ada tiga macam jenis besi yang banyak digunakan yaitu, besi kelabu (grey cast iron), besi ulet atau nodular (nodular cast iron) dan besi putih (white cast iron). Ketiganya memiliki komposisi yang hamper sama (Bahri Samsul, 2010). Serbuk besi diayak sesuai standart agregat halus yaitu lolos ayakan 4,7 mm (No.4) dan diayak dalam kondisi kering (Dry Mix). Tabel 4 adalah kandungan kimia didalam serbuk besi.

Tabel 4. Kandungan serbuk besi

\begin{tabular}{cc}
\hline Komposisi Bahan & Jumlah (\%) \\
\hline Silikon (Si) & $1-3$ \\
Carbon (C) & $2-4$ \\
Mangan (Mn) & 0,8 \\
Fospor (P) & 0,1 \\
Sulfur (S) & 0,05 \\
Besi(Fe) & sisa
\end{tabular}

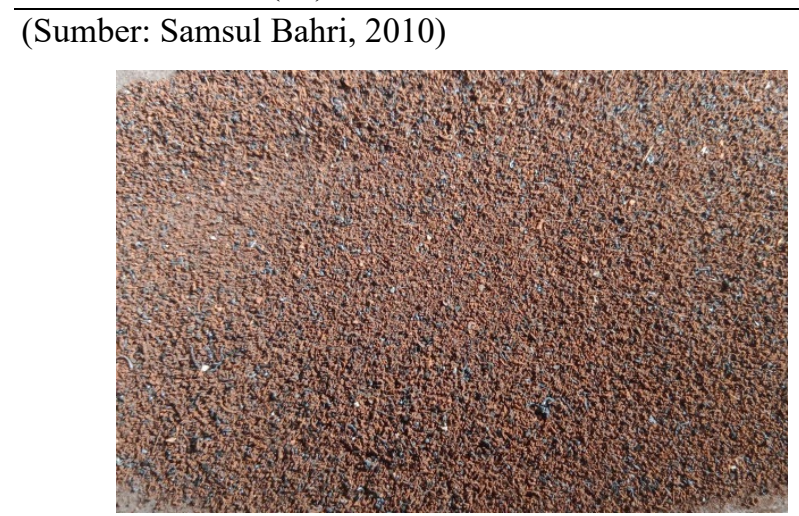

Gambar 5. Limbah serbuk besi 


\section{Hasil pemeriksaan karakteristik aspal}

Dalam penelitian ini menggunakan aspal penetrasi 60/70 berdasarkan spesifikasi (Direktorat Jenderal Bina Marga, 2010)yang telah ditetapkan. Hasil pengujian dapat dilihat pada Tabel 5.

Tabel 5. Hasil pemeriksaan aspal penetrasi $60 / 70$

\begin{tabular}{ccccccc}
\hline No. & $\begin{array}{c}\text { Jenis } \\
\text { Pengujian }\end{array}$ & Satuan & $\begin{array}{c}\text { Hasil } \\
\text { Pengujian }\end{array}$ & Standart Acuan & Spesifikasi & Keterangan \\
\hline 1. & Penetrasi & $\mathrm{Mm}$ & 69,3 & SNI 06-2456-1991 & $60-70$ & Memenuhi \\
2. & Titik Nyala & ${ }^{\circ} \mathrm{C}$. & 322 & SNI 06-2433-1991 & 200 & Memenuhi \\
3. & Titik Bakar & ${ }^{\circ} \mathrm{C}$ & 333 & SNI 06-2433-1991 & 300 & Memenuhi \\
4. & Titik Lembek & ${ }^{\circ} \mathrm{C}$ & 48 & SNI 06-2434-1991 & 52 & Memenuhi \\
5. & Berat Jenis & $\mathrm{Gr} / \mathrm{cc}$ & 1,0209 & SNI 06-2441-1991 & 1,00 & Memenuhi \\
\hline
\end{tabular}

Untuk pengujian aspal pada Tabel 5, didapatkan hasil yang keseluruhannya memenuhi sesuai masing-masing standart yang tercantum pada tabel.

\section{Perencanaan Kadar Aspal Opimal (KAO)}

Dari hasil perhitungan kadar aspal optimal didapatkan hasil spesifikasi yaitu 5,5\%, berikut perhitungan dari KAO : $\mathrm{Pb}=0,035(\% \mathrm{CA})+0,045(\% \mathrm{FA})+0,18(\%$ Filler $)+$ Konstanta

\section{Dimana :}

$$
\begin{array}{ll}
\mathrm{Pb} & =\text { Kadar aspal } \\
\mathrm{CA} & =\% \text { agregat kasar tertahan saringan No.8 } \\
\mathrm{FA} & =\text { Total agregat kasar lolos No. } 8 \text { dan agregat halus tertahan No. } 200 \\
\text { Filler } & =\text { Agregat halus tertahan No. } 200 \\
\text { Konstanta } & =1,0
\end{array}
$$

Jadi :

$$
\begin{aligned}
\mathrm{Pb} & =0,035(7,26)+0,045(93,99)+0,18(1,25)+1,0 \\
& =5,7 \%
\end{aligned}
$$

\section{Pencampuran dari Job Mix Formula}

Kadar campuran

$$
\begin{array}{lll}
- & \text { Agregat kasar } & =23 \% \\
\text { - } & \text { Agregat sedang } & =29,3 \% \\
\text { - } & \text { Agregat halus } & =40 \% \\
\text { - } & \text { Filler } & =2 \% \\
\text { - } & \text { Aspal } & =5,7 \%
\end{array}
$$

Total Campuran

Tabel 6. Campuran serbuk besi kadar 4\%

\begin{tabular}{clccc}
\hline No. & \multicolumn{1}{c}{ Bahan } & Jumlah (\%) & Jumlah (gram) & Komulatif \\
\hline 1. & Aspal & $5,7 \%$ & 68.4 & 68.4 \\
2. & Agregat Kasar & $23 \%$ & 276 & 344.4 \\
3. & Agregat Sedang & $29,3 \%$ & 351.6 & 696 \\
4. & Agregat Halus & $36 \%$ & 432 & 1128 \\
5. & Filler & $2 \%$ & 24 & 1152 \\
6. & Serbuk Besi & $4 \%$ & 48 & 1200 \\
\hline
\end{tabular}


Tabel 7. Campuran serbuk besi kadar $4.5 \%$

\begin{tabular}{clccc}
\hline No. & \multicolumn{1}{c}{ Bahan } & Jumlah (\%) & Jumlah (gram) & Komulatif \\
\hline 1. & Aspal & $5.70 \%$ & 68.4 & 68.4 \\
2. & Agregat Kasar & $23 \%$ & 276 & 344.4 \\
3. & Agregat Sedang & $29.30 \%$ & 351.6 & 696 \\
4. & Agregat Halus & $35.5 \%$ & 426 & 1122 \\
5. & Filler & $2 \%$ & 24 & 1146 \\
6. & Serbuk Besi & $4.5 \%$ & 54 & 1200 \\
\hline
\end{tabular}

Tabel 8. Campuran serbuk besi kadar 5\%

\begin{tabular}{clccc}
\hline No. & \multicolumn{1}{c}{ Bahan } & Jumlah (\%) & Jumlah (gram) & Komulatif \\
\hline 1. & Aspal & $5.70 \%$ & 68.4 & 68.4 \\
2. & Agregat Kasar & $23 \%$ & 276 & 344.4 \\
3. & Agregat Sedang & $29.30 \%$ & 351.6 & 696 \\
4. & Agregat Halus & $35.0 \%$ & 420 & 1116 \\
5. & Filler & $2 \%$ & 24 & 1140 \\
6. & Serbuk Besi & $5.0 \%$ & 60 & 1200 \\
\hline
\end{tabular}

\section{Hasil pengujian Marshall Test}

Untuk hasil penelitian dan pengujian dari benda uji campuran aspal dengan dan tanpa bahan tambah limbah serbuk besi sebagai agregat halus menurut spesifikasi (Direktorat Jenderal Bina Marga, 2010) dapat dilihat pada Tabel 9.

Tabel 9. Hasil pengujian marshall test rata-rata

\begin{tabular}{|c|c|c|c|c|c|c|}
\hline $\begin{array}{c}\text { (\%) Serbuk } \\
\text { Besi }\end{array}$ & $\begin{array}{l}\text { Stabilitas } \\
(\mathrm{Kg})\end{array}$ & $\begin{array}{l}\text { VFA } \\
(\%)\end{array}$ & VIM (\%) & $\begin{array}{l}\text { VMA } \\
(\%)\end{array}$ & Flow $(\%)$ & MQ (\%) \\
\hline 0 & 977 & 74,97 & 4,14 & 17,29 & 3,17 & 309,31 \\
\hline 4 & 788 & 83,28 & 2,46 & 15,84 & 3,33 & 236,74 \\
\hline 4,5 & 769 & 85,75 & 2,02 & 15,46 & 2,93 & 242,11 \\
\hline 5 & 731 & 88,76 & 1,50 & 15,01 & 2,97 & 246,80 \\
\hline Spesisikasi & Min 800 & $\begin{array}{l}\text { Min } \\
65 \%\end{array}$ & $3-5 \%$ & $\begin{array}{l}\text { Min } \\
15 \%\end{array}$ & $2-4 \mathrm{~mm}$ & Min 250 \\
\hline Pemadatan & \multicolumn{6}{|c|}{$75 \times 2$} \\
\hline Kadar Aspal & \multicolumn{6}{|c|}{$5,7 \%$} \\
\hline
\end{tabular}

\section{Stabilitas Marshall}

Merupakan kemampuan suatu benda uji campuran aspal untuk menerima dan menahan beban tanpa adanya perubahan bentuk. Stabilitas ini adalah parameter untuk mengukur seberapa kekuatan lapisan perkerasan aspal yang akan digunakan. 

(AC-WC)

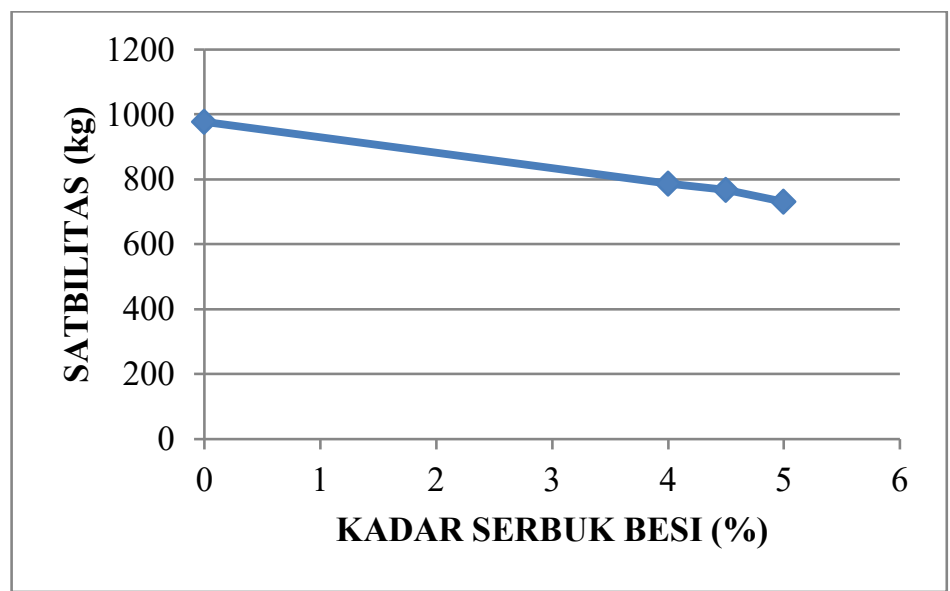

Gambar 6. Hubungan stabilitas dengan kadar serbuk besi

Dari Gambar 6 didapatkan hasil pengujian stabilitas menunjukan penurunan nilai stabilitas seiring bertambahnya kadar. Penurunan bias terjadi karena kurangnya pencampuran yang merata saat penggorengan dan adanya volume rongga yang tinggi sehingga aspal tidak terlalu kuat saat menerima beban dan terjadi keretakan. Nilai tertinggi terdapat padar kadar 0\% dengan nilai $977 \mathrm{~kg}$ yang sudah memenuhi standart (Direktorat Jenderal Bina Marga, 2010) yaitu minimal $800 \mathrm{~kg}$.

\section{Void In Mixture (VIM)}

Rongga dalam campuran (VIM) yaitu rongga udara yang berada didalam campuran aspal beton yang telah dipadatkan.

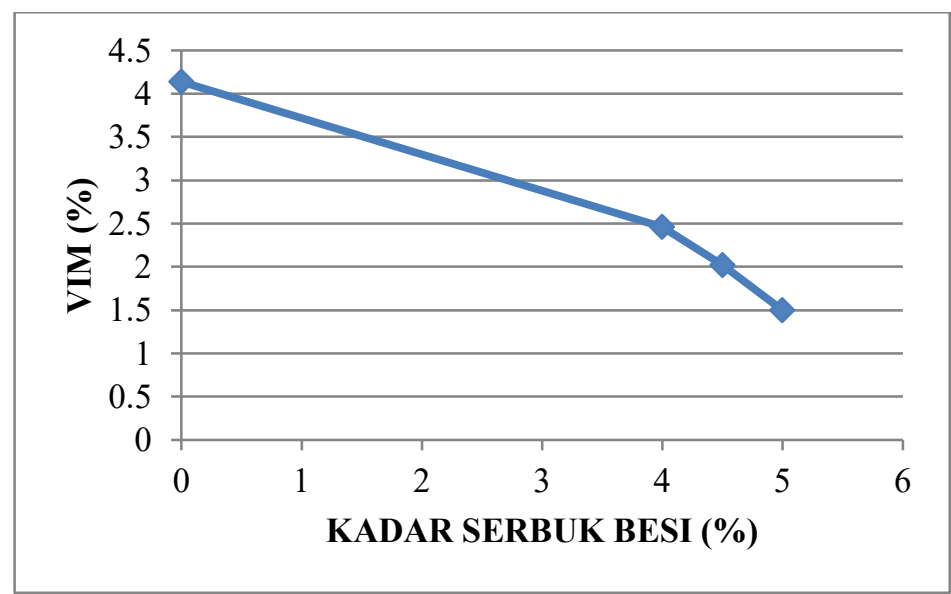

Gambar 7. Hubungan Void In Mixture dengan kadar serbuk besi

Dari hasil yang memenuhi adalah dengan kadar 0\% dengan nilai 4,14\% dari batas minimum (Direktorat Jenderal Bina Marga, 2010) yaitu 3-5\%. Pada gambar 7 menunukkan, setiap penambahan kadar nilai VIM semakin mengalami penurunan. Penurunan ini menunjukkan kecilnya rongga yang tertutupi serbuk besi mengakibtakan campuran rapat oleh air dan udara, sehingga menimbulkan kegetasan.

\section{Void in Mineral Aggregat (VMA)}

Nilai rongga dalam mineral agregat (VMA) untuk mengetahui tingkat kekuatan perkerasan jalan. Nilai VMA dipengaruhi oleh tekstur dan juga pemadatan. Hasil dari pengujian nilai VMA dengan menggunakan standart spesifikasi (Direktorat Jenderal Bina Marga, 2010) dapat dilihat pada Gambar 8. 


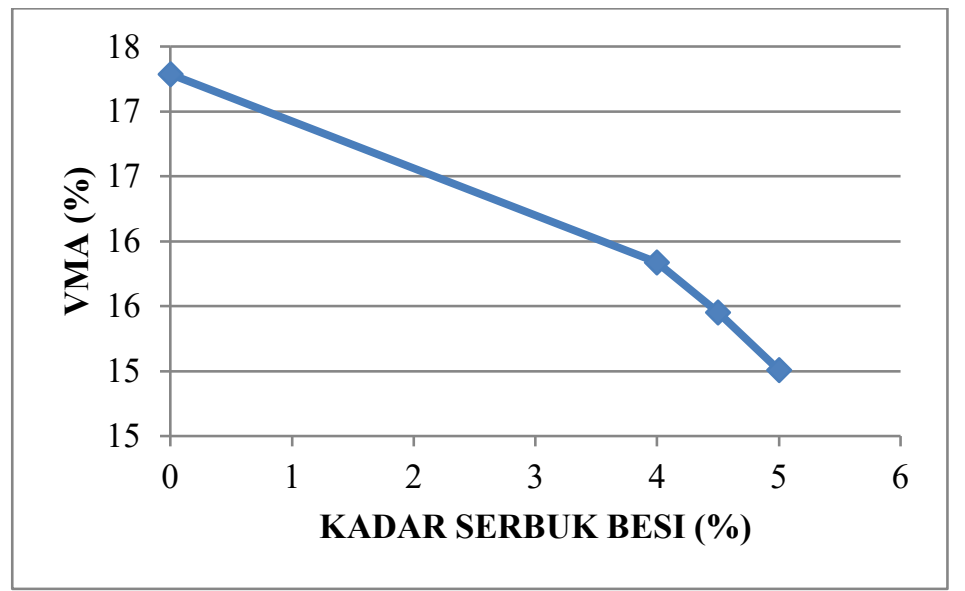

Gambar 8. Hubungan Void in Mineral Aggregat dengan kadar serbuk besi

Nilai VMA pada Gambar 8 menunjukkan penurunan, namun dari keseluruhan kadar masih memenuhi standart spesifikasi (Direktorat Jenderal Bina Marga, 2010) yaitu minimal 15\%. Untuk nilai VMA yang terlalu tinggi dapat menyebabkan bleeding saat aspal menerima beban dan jika nilai VMA rendah dapat menyebabkan kurangnya pengikatan aspal sehingga terjadi reveling.

\section{Void Filled with Asphalt (VFA)}

Void Filled with Asphalt atau rongga terisi oleh aspal (VFA) merupakan rongga pori aspal beton padat yang terisi oleh aspal dan tidak termasuk aspal yang diserap oleh agregat. Gambar 9 menunjukan hasil dari pengujian campuran aspal tanpa dan dengan bahan tambah limbah serbuk besi menurut standart spesifikasi (Direktorat Jenderal Bina Marga, 2010).

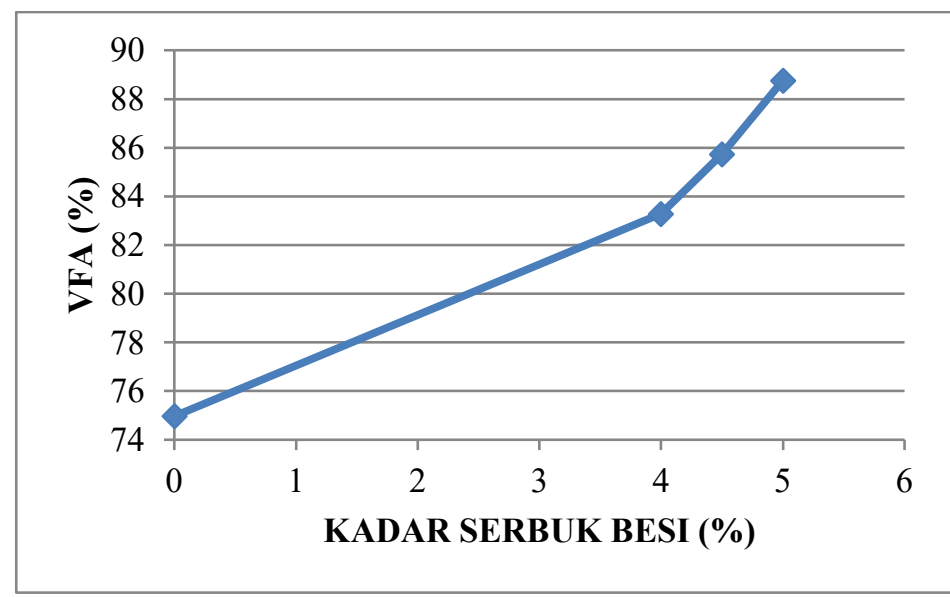

Gambar 9. Hubungan Void Filled with Asphalt dengan kadar serbuk besi

Untuk hasil pengujian VFA menurut Gambar 9 semakin mengalami kenaikan ketika kadar semakin bertambah. Kenaikan nilai VFA dikarenakan rongga diantra partikel agregat (VMA) terisi oleh aspal dengan baik, sehingga kekedapan campuran terhadap air dan udara menjadi tinggi. Nilai terendah pada kadar 0\% dengan nilai 74,97\%, tetapi masih memenuhi persyaratan (Direktorat Jenderal Bina Marga, 2010) dengan minimum 65\%.

\section{Kelelehan plastis (Flow)}

Perkerasan jalan ketika menerima beban lalu lintas akan mengalami perubahan bentuk plastis yang disebut dengan flow. Jika nilai dari flow tinggi, maka bentuk mudah berubah saat menerima beban. Dan sebaliknya, jika nilai flow rendah maka bmenjadi kaku dan mudah retak. 

(AC-WC)

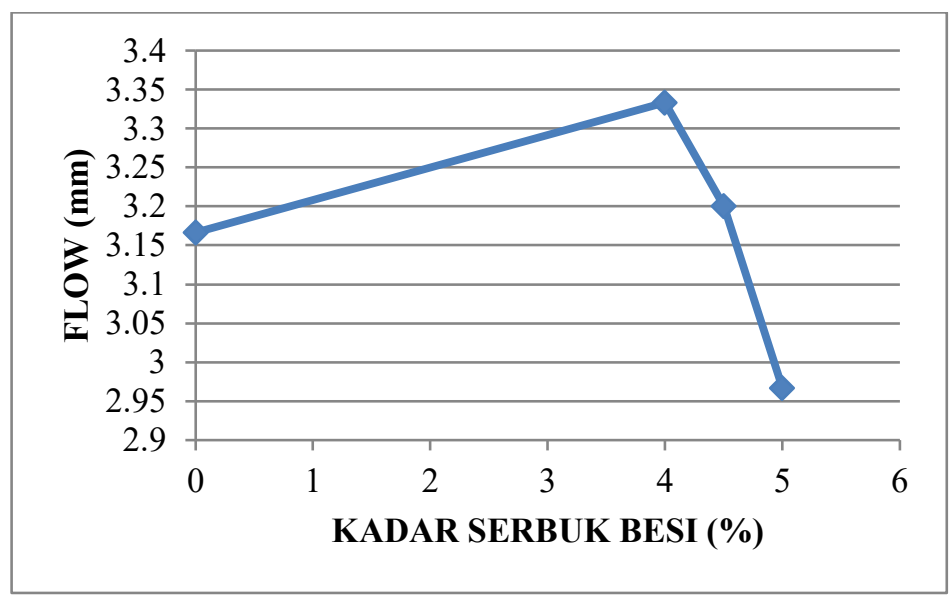

Gambar 10. Hubungan Flow dengan kadar serbuk besi

Menyajikan dari hasil pengujian nilai flow menurut Gambar 10 juga menunjukan kenaikan dan penurunan, tetapi nilai keseluruhan flow masih memenuhi standart (Direktorat Jenderal Bina Marga, 2010) untuk nilai flow yaitu 2-4 mm. Nilai flow dipengaruhi oleh kadar aspal, yang mana jika kadar aspal tinggi maka membuat nilai flow semakin tinggi. Dan sebaliknya, kadar aspal rendah nilai flow juga semakin rendah.

\section{Marshall Quotien (MQ)}

Untuk perkerasan jalan yang memenuhi syarat harus memiliki stabilitas yang kuat dan kelelehan plastis yang baik saat menerima beban lalu lintas secara langsung. Marshall Quotien merupakan keseimbnagan dari nilai stabilitas dan nilai kelelehan plastis (flow). Berikut dapat dilihat hasil nilai pengujian Marshall Quotien pada Gambar 11.

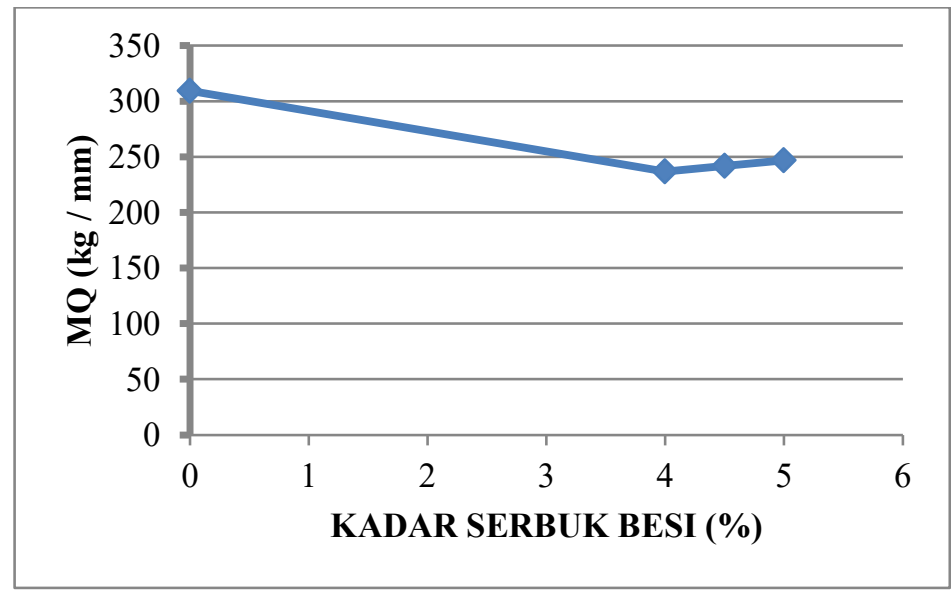

Gambar 11. Hubungan MQ dengan kadar serbuk besi

Nilai Marshall Quotien mengalami penurunan seperti pada Gambar 11 diatas. Penurunan MQ terpengaruhi dari nilai stabilitas dan flow yang rendah. Jika campuran aspal memiliki stabilitas tinggi dan flow rendah dapat menyebabkan campuran aspal kaku dan getas. Dan jika stabilitas rendah dan flow tinggi menyebabkan campuran aspal cenderung plastis. Dari kadar serbuk besi yang memenuhi yaitu kadar $0 \%$ dengan nilai $309,31 \mathrm{~kg} / \mathrm{mm}$, yang mana standart dari (Direktorat Jenderal Bina Marga, 2010) dengan nilai minimal $250 \mathrm{~kg} / \mathrm{mm}$.

\section{KESIMPULAN DAN SARAN}

\section{Kesimpulan}

Dari hasil penelitian yang telah dilakukan dapat disimpulkan sebagai berikut :

1. Diperoleh hasil yang berbeda-beda dari nilai Marshall Properties dengan bahan tambah limbah serbuk besi,yaitu dari stabilitas, kelelehan plastis (Flow), VIM, VFA, VMA dan MQ. Dari kadar variasi 0\%, 4\%, 4,5\% dan 5\% hanya dapat menenuhi persyaratan pada nilai Marshall Properties adalah VFA, VMA dan kelelehan plastis (Flow). Tetapi tidak dapat memenuhi persyaratan dari Stabilitas, VIM, dan MQ. Sehingga penggunaan limbah 
serbuk besi tidak dapat dijadikan sebagai bahan subtitusi secara keseluruhan dalam campuran agregat halus pada aspal AC-WC.

2. Hasil nilai perbandingan dengan kadar $0 \%, 4 \%, 4,5 \%, 5 \%$ tertinggi tanpa dan dengan bahan tambah yang terdiri dari, stabilitas tanpa bahan tambah kadar $0 \%$ yaitu $997 \mathrm{~kg}$ dan dengan bahan tambah kadar 4\% yaitu $788 \mathrm{~kg}$, VIM tanpa bahan tambah kadar $0 \%$ yaitu $4,14 \%$ dan dengan bahan tambah kadar $4 \%$ yaitu $2,46 \%$, VFA tanpa bahan tambah kadar $0 \%$ yaitu 74,97\% dan dengan bahan tambah kadar 5\% yaitu 88,76\%, VMA tanpa bahan tambah kadar $0 \%$ yaitu $17,29 \%$ dan dengan bahan tambah kadar 4\% yaitu 15,84\%, Flow tanpa bahan tambah kadar $0 \%$ yaitu 3,17 mm dan dengan bahan tambah kadar $4 \%$ yaitu 3,33 mm dan MQ tanpa bahan tambah kadar $0 \%$ yaitu $309,31 \mathrm{~kg} / \mathrm{mm}$ dan dengan bahan tambah kadar $5 \%$ yaitu $246,80 \mathrm{~kg} / \mathrm{mm}$. Dari hasil tersebut dapat diketahui untuk campuran aspal dengan bahan tambah serbuk besi dari kadar 4\%, 4.5\%, 5\%, yang paling mendekati syarat spesifikasi adalah dengan kadar $4 \%$.

\section{Saran}

Berdasarkan dari hasil penelitian yang diperoleh dapat direkomendasikan saran sebagai berikut :

1. Pada bahan tambah serbuk besi sebagai agregat halus pada campuran aspal sebaiknya tidak digunakan karena belum sepenuhnya memenuhi standart nilai Marshall Properties.

2. Untuk memenuhi tingkat kenyamanan dan hasil yang maksimal dalam penerapan aspal pada jalan raya, sebaiknya perlu dilakukan pengujian kembali agar nilai dari Marshall Properties keseluruhannya dapat memenuhi standart yang telah ditetapkan.

3. Untuk penelitian selanjutnya disarankan untuk melakukan uji coba menggunakan limbah serbuk besi sebagai bahan tambah agregat halus dengan kadar antara 1\% hingga 4\%, dikarenkan pada penelitian ini kadar 4\% hampir memenuhi standart spesifikasi uji Marshall Properties.

\section{DAFTAR PUSTAKA}

Al-tuwayyij, H., \& Issa, S. (2020). Influence of Iron-Filings on Marshall and Volumetric Properties of Asphalt Concrete. 6(9), 1684-1696.

Arifiardi Winoto; Purnomo, Adhi, I. H. (2016). Pengaruh Penggunaan Pasir Pantai Carita Sebagai Campuran Agregat Halus Pada Lapis Permukaan Aspal Beton Terhadap Persyaratan Parameter Marshall. Jurnal Menara, $\begin{array}{llllllll}X I(\text { Vol } & 11 & \text { No } & 1 & \text { (2016): } & \text { Menara: Jurnal Teknik } & \text { Sipil), } & 16 .\end{array}$ http://journal.unj.ac.id/unj/index.php/menara/article/view/7969

Badan Standardisasi Nasional. (1991). SNI 06-2433: Cara Uji Titik Nyala Dan Titik Bakar Aspal Dengan Alat Cleveland Open Up. Badan Standardisasi Nasional.

Badan Standardisasi Nasional. (1991). SNI 06-2434: Cara Uji Titik Lembek Aspal dengan Alat Cincin dan Bola (Ring and Ball). Badan Standardisasi Nasional.

Badan Standardisasi Nasional. (1991). SNI 06-2456: Cara uji penetrasi aspal. Badan Standardisasi Nasional, 1-14.

Badan Standardisasi Nasional. (2008). SNI 03-1970: Cara Uji Berat Jenis dan Penyerapan Air Agregat Halus. Badan Standar Nasional Indonesia.

Badan Standardisasi Nasional. (2008). SNI 1969: Cara uji berat jenis dan penyerapan air agregat kasar. Badan Standardisasi Nasional.

Bahri, S. (2017). Pemanfaatan Limbah Serbuk Besi Sebagai Agregat Halus Pada Campuran Aspal Panas. Inersia, Jurnal Teknik Sipil, 9(2), 39-46. https://doi.org/10.33369/ijts.9.2.39-46

Bahri Samsul, D. A. S. I. (2010). Pengaruh Limbah Serbuk Besi Sebagai Pengganti Sejumlah Agregat Halus Terhadap Campuran Aspal. 1(2), 25-32.

Budianto, M. D. ., \& Lubis, Z. (2020). Alternatif Penggunaan Agregat Halus Batu Kapur Mantup Dalam Campuran Aspal Panas Ac-Wc. 4(1), 559-570.

Direktorat Jenderal Bina Marga. (2010). Spesifikasi Umum 2010 (Revisi 3) Divisi 6 (pp. 1-89).

Santosa, P. D. (2019). Pengaruh Limbah Serbuk Besi Sebagai Pengganti Sejumlah Filler Terhadap HRS (Hot Rolled Sheet).

Susanto, H. A. (2020). Pengaruh Penggunaan Filler Pasir Besi Dan Semen Dalam Campuran Asphalt Concrete Wearing Course (AC-WC). Techno (Jurnal Fakultas Teknik, Universitas Muhammadiyah Purwokerto), 21(1), 37. https://doi.org/10.30595/techno.v21i1.7230 
Penggunaan Limbah Serbuk Besi Sebagai Campuran

Umma Chintya Devi, et al.

Agregat Halus pada Asphalt Concrete-Wearing Course (AC-WC) 